\title{
Citrullination regulates the expression of insulin-like growth factor-binding protein 1 (IGFBP1) in ovine uterine luminal epithelial cells
}

\author{
Coleman H Young ${ }^{1}$, Heather M Rothfuss ${ }^{1}$, Philip F Gard ${ }^{1}$, Aaron Muth², Paul R Thompson², \\ Ryan L Ashley ${ }^{3}$ and Brian D Cherrington ${ }^{1}$ \\ ${ }^{1}$ Department of Zoology and Physiology, University of Wyoming, Laramie, Wyoming, USA, ${ }^{2}$ Department of \\ Biochemistry and Molecular Pharmacology, University of Massachusetts Medical School, Worcester, Massachusetts, \\ USA and ${ }^{3}$ Department of Animal and Range Sciences, New Mexico State University, Las Cruces, New Mexico, USA \\ Correspondence should be addressed to B D Cherrington; Email: bcherrin@uwyo.edu
}

\begin{abstract}
There are five peptidylarginine deiminase (PAD) isozymes designated as PADs 1, 2, 3, 4 and 6, and many are expressed in female reproductive tissues. These enzymes post-translationally convert positively charged arginine amino acids into neutral citrulline residues. Targets for PAD-catalyzed citrullination include arginine residues on histone tails, which results in chromatin decondensation and changes in gene expression. Some of the first studies examining PADs found that they are localized to rodent uterine epithelial cells. Despite these findings, the function of PAD-catalyzed citrullination in uterine epithelial cells is still unknown. To address this, we first examined PAD expression in uterine cross-sections from pregnant ewes on gestation day 25 (d25). Immunohistochemistry revealed that the levels of PADs 2 and $\mathbf{4}$ are robust in luminal and glandular epithelia compared with those of PADs 1 and 3. As PADs 2 and 4 have well-characterized roles in histone citrullination, we next hypothesized that PADs citrullinate histones in these uterine cells. Examination of caruncle lysates from pregnant ewes on gestation d25 and an ovine luminal epithelial (OLE) cell line shows that histone $\mathrm{H} 3$ arginine residues 2, 8, 17 and 26 are citrullinated, but histone $\mathrm{H} 4$ arginine 3 is not. Using a pan-PAD inhibitor, we next attenuated histone citrullination in OLE cells, which resulted in a significant decrease in the expression of insulin-like growth factor-binding protein 1 (IGFBP1) mRNA. As IGFBP1 is important for the migration and attachment of the trophectoderm to uterine endometrium, our results suggest that PAD-catalyzed citrullination may be an important post-translational mechanism for the establishment of pregnancy in ewes.

Reproduction (2017) 153 1-10
\end{abstract}

\section{Introduction}

There are five peptidylarginine deiminase (PAD) enzymes (PADs 1-4 and 6) with widespread, and often overlapping, expression in tissues and cells (Vossenaar et al. 2003). This calcium-dependent enzyme family post-translationally converts arginine amino acids in proteins to the non-coded residue citrulline. One exception to this is PAD6, which does not possess catalytic activity and is restricted to fibrous cytoplasmic lattices in mouse oocytes (Wright et al. 2003). PAD activity, termed deimination or citrullination, results in the loss of the positively charged guanidinium group from arginine residues. This post-translational modification occurs on arginine residues in cytoplasmic proteins such as $\beta$-actin and $\beta$-tubulin and in multiple histone isotypes (Hagiwara et al. 2005, Jiang et al. 2013, Kholia et al. 2015). Although the functional consequences of this modification on cytoplasmic proteins remain largely unclear, histone citrullination results in changes in chromatin structure to alter gene expression (Wang et al. 2004). To date, only PADs 2 and 4 have been shown to localize to the nucleus and citrullinate arginine residues on histone tails (Wang et al. 2004, Cherrington et al. 2012). Some of the first studies investigating PAD enzymes discovered robust expression and catalytic activity in rodent uteri (Takahara et al. 1989, Terakawa et al. 1991). Despite this, the functional role of PAD-catalyzed citrullination in the uterus is still unknown. To address this, we have investigated PAD-catalyzed citrullination in uterine tissues from pregnant ewes on gestation day 25 (d25) and an ovine luminal epithelial (OLE) cell line.

PADs 1,2 and 4 are expressed in rodent uterine tissue in luminal and glandular epithelial cells (Takahara et al. 1992, Horibata et al. 2012). In addition, a genomic study found that PAD mRNA levels are highest in mouse uterine tissue compared 
with all of the other 50 tissues examined (Barrett et al. 2009). Expression changes over the phases of the estrous cycle with highest levels of PADs 2 and 4 during estrus, whereas PAD1 is elevated during proestrus (Terakawa et al. 1991, Takahara et al. 1992). Our past work and that of others shows that ovariectomy of mice eliminates PAD expression in the uterine luminal and glandular epithelial cells, but that it is restored by exogenous estrogen treatment (Terakawa et al. 1991, Takahara et al. 1992, Rus'd et al. 1999, Horibata et al. 2012). In terms of uterine physiology, estrogen produced by the growing follicle is absolutely critical during the proliferative phase of the estrous cycle for the regeneration and growth of the endometrium. Although their expression is clearly estrogen regulated, it is not known whether PADs play a role in endometrial growth during the proliferative phase of the estrous cycle.

PADs are also expressed in mouse uterine tissue during pregnancy (Arai et al. 1995). Arai et al. found that PAD activity sharply increases from days 8 to 10 of pregnancy in mice, but decreases at later stages (Arai et al. 1995). PADs are expressed in mouse decidual cells, which differentiate from the uterine stromal cells surrounding the site of embryo implantation; however, it is important to note that decidualization is not thought to occur in ovine stromal cells. Importantly, no PAD expression is detected in mouse embryoderived trophoblast cells (Arai et al. 1995). Despite these initial findings, the function of PAD-catalyzed citrullination in uterine tissues during pregnancy is unclear.

In the ewe, the placentome unit is composed of the fetal cotyledon and maternal caruncle. At approximately day 13-14 of pregnancy, the trophoblast begins to attach and forms a strong contact with maternal luminal epithelial cells. To achieve attachment, luminal and glandular epithelial cells initiate gene programs to produce numerous molecules collectively termed the histotroph, which is then secreted into the uterine lumen (Bazer 1975, Kane et al. 1997). The histotroph is required for conceptus survival and growth and to stimulate uterine receptivity for implantation/attachment (Roberts et al. 1987, Carson et al. 2000). Supporting this, the ewe uterine gland-knockout model, which lacks uterine glandular epithelial cells, cannot maintain pregnancy (Gray et al. 2001a,b, 2002). Many important genes expressed in ewe uterine luminal and glandular epithelial cells during early pregnancy have been identified (Gray et al. 2006, Spencer et al. 2008, Satterfield et al. 2009). For example, insulin-like growth factor-binding protein 1 (IGFBP1) is produced and secreted by uterine epithelial cells to stimulate migration and attachment of the trophectoderm to maternal tissue (Gleeson et al. 2001). To the best of our knowledge, little work has investigated the role of histone modifications in regulating gene expression of the histotroph in ewe uterine luminal epithelial cells.

Our studies show that PADs 2 and 4 are highly expressed, catalytically active and citrullinate histone $\mathrm{H} 3$ arginine residues 2, 8, 17 and 26 in gestation $\mathrm{d} 25$ ewe uterine epithelia. To investigate gene expression in uterine cells, we used the OLE cell line that only expresses PADs 2 and 4 (Johnson et al. 1999). These cells display strong PAD2 and PAD4 staining in their nuclei and only citrullinate histone $\mathrm{H} 3$ arginine residues similar to patterns identified in gestation $\mathrm{d} 25$ ewe caruncle lysates. After treatment of OLE cells with the pan-PAD inhibitor biphenyl-benzimidazole$\mathrm{Cl}$-amidine (BB-ClA), expression of IGFBP1 mRNA is significantly decreased. Overall, our work indicates that PAD-catalyzed citrullination regulates gene expression in uterine luminal epithelial cells, and this mechanism may be necessary for maintaining early pregnancy in the ewe.

\section{Materials and methods}

\section{Materials}

The rabbit anti-PAD2 antibody was purchased from Proteintech (12110-1-AP, Rosemont, IL, USA) and the rabbit anti-histone $\mathrm{H} 4$ cit 3 antibody was purchased from EMD Millipore (07-596). The rabbit anti- $\beta$-actin (ab8227), histone H3 total (ab1791), H3cit 2,8,17 (ab5103), H3Cit 26 (ab19847) and PAD1 (ab24008) antibodies were purchased from Abcam. Rabbit anti-PAD3 and PAD4 antibodies were purchased from Antibodies-online Inc. (ABIN347067 Atlanta, GA, USA) and Sigma-Aldrich (P4749) respectively. The goat antirabbit HRP secondary antibody was purchased from Jackson ImmunoResearch (111-035-003). The PAD inhibitor, biphenylbenzimidazole-Cl-amidine (BB-ClA), was synthesized by Dr Paul R Thompson (University of Massachusetts) as described previously (Knight et al. 2015).

\section{Cell culture}

OLE cells, a generous gift from Dr Greg Johnson (Texas A\&M), were maintained in high-glucose DMEM containing $2 \mathrm{mM}$ glutamine, $100 \mathrm{U}$ penicillin/mL, $100 \mu$ gstreptomycin $/ \mathrm{mL}$ and $10 \%$ fetal bovine serum (FBS) (HyClone, Logan, UT, USA). All cells were grown in $5 \% \mathrm{CO}_{2}$ at $37^{\circ} \mathrm{C}$ in a humidified environment.

\section{Ewe uterine tissue samples}

Rambouillet ewes (Ovis aries) were maintained with ad libitum access to food and water. Animal treatment and tissue collection are described in detail in Quinn et al. (2014). Euthanasia and tissue collection were performed in accordance with the guidelines outlined in the Report of the AVMA on Euthanasia. The New Mexico State University Animal Care and Use Committee reviewed and approved all experimental procedures using animals. 


\section{Immunohistochemistry (IHC) and immunofluorescence (IF)}

IHC and IF experiments were carried out as described previously (Cherrington et al. 2010). Briefly, slides were deparaffinized in $3 \times 5$-min washes in xylene followed by sequential 5-min rehydrations in 100, 95 and 75\% EtOH. Endogenous peroxidase activity was blocked by incubating slides in $0.5 \%$ hydrogen peroxide in cold methanol for $10 \mathrm{~min}$. Next, antigen retrieval was conducted by submerging the slides in $0.01 \mathrm{M}$ sodium citrate and boiling $2 \times$ for 12 min. After cooling, slides were washed in $1 \times$ PBS and then blocked in $10 \%$ normal goat serum and $1 \times$ casein (Vector Labs, Burlingame, CA, USA) diluted in $1 \times$ PBS for $20 \mathrm{~min}$ at room temperature in a humidified chamber. After removing excess blocking solution, slides were incubated with anti-PAD antibodies diluted 1:100 in 1× PBS for $2 \mathrm{~h}$ at $37^{\circ} \mathrm{C}$. For negative controls, slides were incubated with an equal mass of non-specific rabbit IgG. After washing three times in PBS, slides were incubated for $20 \mathrm{~min}$ at room temperature with a biotinylated secondary antibody diluted $1: 200$ in $1 \times$ PBS. After three washes in PBS, IHC slides were incubated in DAB chromogen (Vector Labs) solutions according to the manufacturer's protocol, washed and then counterstained with hematoxylin and coverslip mounted. Images were taken with a Zeiss Axio Vert.A1 microscope using the 10 and $40 \times$ objectives.

For IF, OLE cells were grown in MatTek $35 \mathrm{~mm}$ glass bottom dishes (Ashland, MA, USA). Cells were fixed, permeabilized and then incubated in sequential steps with primary antibodies and fluorophore-conjugated (488) secondary antibodies (A11008, Thermo Scientific). After washing three times in $1 \times$ PBS, cells were stained with DAPI. For each experiment, duplicate dishes were incubated with an equal mass of non-specific rabbit IgG as a negative control (1-1000, Vector Labs). All samples were imaged on a Zeiss LSM 710 confocal microscope under a $40 \times$ objective.

\section{PAD activity assay}

The Color Development Reagent (COLDER) assay was carried out as described previously (Knuckley et al. 2010). Briefly, caruncles were lysed in modified RIPA buffer $(50 \mathrm{mM}$ Tris-Cl pH 8, $150 \mathrm{mM} \mathrm{NaCl}, 1 \%$ NP-40, $0.25 \%$ Na-deoxycholate), sonicated and then cleared by centrifugation. Lysates were incubated with $50 \mu \mathrm{g} / \mathrm{mL}$ of urease (Sigma-Aldrich) to eliminate interference from urea and methylurea. $20 \mu \mathrm{g}$ from three independent d25 ewe caruncle lysates were then incubated with $\mathrm{N} \alpha$-benzoylarginine ethyl-ester hydrochloride (BAEE) (Sigma-Aldrich) for $18 \mathrm{~h}$ at $55^{\circ} \mathrm{C}$ in the presence of $10 \mathrm{mM}$ calcium chloride or $50 \mathrm{mM}$ EGTA. Identical samples lacking BAEE were also incubated as a no-substrate control. Concentration was compared with a citrulline standard curve that was linear throughout the test range. Experiments were repeated at least three times, and values are expressed as means \pm S.E.M. Means were separated using Student's $t$-test, and * indicates significantly different means $(P<0.05)$.

\section{Histone purification}

For PAD inhibitor studies, OLE cells were treated with vehicle or $2 \mu \mathrm{M}$ BB-ClA for $3 \mathrm{~h}$ or for $6 \mathrm{~h}$, which included a second spike after the first $3 \mathrm{~h}$. Histones were purified using an acid extraction method as described previously (Shechter et al. 2007). Briefly, cells were washed with $1 \times$ PBS and lysed with hypotonic lysis buffer $(10 \mathrm{mM}$ Tris $\mathrm{pH} 8,1 \mathrm{mM}$ $\mathrm{KCl}, 1.5 \mathrm{mM} \mathrm{MgCl} 2,0.5 \% \mathrm{NP}-40,1 \mathrm{mM}$ DTT, $1 \times$ protease inhibitor, $1 \times$ PMSF, $\mathrm{dH}_{2} \mathrm{O}$ ). The lysate was placed on ice for $30 \mathrm{~min}$, and then nuclei were isolated by centrifugation $\left(10,000 \mathrm{~g}\right.$ for $10 \mathrm{~min}$ at $\left.4^{\circ} \mathrm{C}\right)$. The nuclei pellet was dissolved in $0.4 \mathrm{M} \mathrm{H}_{2} \mathrm{SO}_{4}$ and rotated overnight at $4^{\circ} \mathrm{C}$. After centrifugation at $17,000 \mathrm{~g}$ for $10 \mathrm{~min}$ at $4{ }^{\circ} \mathrm{C}$, the supernatant was collected, $100 \%$ TCA was added ( $20 \%$ of total volume) and incubated on ice for $20 \mathrm{~min}$. Centrifugation at 17,000 $\mathrm{g}$ for $10 \mathrm{~min}$ at $4^{\circ} \mathrm{C}$ was again conducted, the supernatant was then discarded and the pellet was washed with $300 \mu \mathrm{L}$ of cold acetone. The purified histone pellets were air dried, resuspended in $50 \mu \mathrm{L}$ of nanopure $\mathrm{H}_{2} \mathrm{O}$, and quantified using a Pierce $660 \mathrm{~nm}$ protein assay.

\section{Western blots}

Positive controls for PAD antibodies were generated by overexpressing human PAD 1-4 plasmids for $24 \mathrm{~h}$ following a Mirus Bio (Madison, WI, USA) TranIT-2020 transfection protocol. Positive controls for histone antibodies were generated by in vitro citrullination of bulk histones. OLE cells and snap-frozen d25 ewe caruncles were lysed with RIPA buffer containing $50 \mathrm{mM}$ Tris, $150 \mathrm{mM} \mathrm{NaCl}, 0.1 \%$ SDS, $0.5 \%$ deoxycholate, $1 \%$ Triton X-100, $1 \mathrm{mM}$ PMSF and $1 \times$ protease inhibitor (Thermo Scientific). Protein concentration of lysates and purified histones was measured by Pierce $660 \mathrm{~nm}$ protein assay before gel loading to ensure equal protein loading. $6 \times$ sample buffer consisting of $0.5 \mathrm{M}$ Tris- $\mathrm{HCl}$ (pH 6.8), 60\% glycerol, $30 \mathrm{mM}$ DTT and $6 \%$ SDS was added into samples to yield a final concentration of $1 \times$ sample buffer and then boiled at $95^{\circ} \mathrm{C}$ for $5 \mathrm{~min}$. The samples were subjected to SDS-PAGE using 12 or $15 \%$ gels (acrylamide:bis-acrylamide ratio of 29:1) and subsequently transferred to Immobilon PVDF membranes (EMD Millipore). Membranes were blocked in $1 \times$ casein (Vector Labs) diluted in Tris-buffered saline containing $0.1 \%$ Tween 20 (TBS-T) overnight at $4^{\circ} \mathrm{C}$. Primary antibodies were incubated overnight at $4^{\circ} \mathrm{C}$ : Anti-PAD1 (1:1000), Anti-PAD2 (1:2000), Anti-PAD3 (1:800) or Anti-PAD4 (1:2000), H3cit 2,8,17 (1:1000), H3cit 26 (1:500), H4cit 3 (1:500), H3 total $(1: 5000)$. The following morning, membranes were washed in TBS-T, followed by 2 -h incubation at room temperature with 1:10,000 anti-rabbit HRP secondary antibody. All blots were washed for $50 \mathrm{~min}(5 \times 10 \mathrm{~min})$ with TBS-T after secondary antibody incubation and then visualized with a Bio-Rad Chemidoc XRS using SuperSignal West Pico and Femto chemiluminescence substrate (Pierce). To confirm equal protein loading, membranes were stripped and re-probed with anti- $\beta$-actin or anti-total histone $\mathrm{H} 3$. Quantitative densitometry analysis was conducted with Bio-Rad Image Lab software. Anti-modified citrulline (AMC) western blots were performed according to the manufacture's 
protocol (EMD Millipore). Experiments were repeated at least independent times, and values are expressed as the mean \pm S.E.M. Means were separated using Newman-Keuls ANOVA and * indicates significantly different means $(P<0.05)$.

\section{qPCR}

RNA from OLE cells was purified according to the Omega Bio-Tek Total RNA Kit protocol (Omega BioTek, Inc., Norcross, GA, USA). $1 \mu \mathrm{g}$ of resulting RNA was reverse transcribed using iScript Reverse Transcription Supermix for RT-qPCR (Bio-Rad). Complementary DNA was subject to real-time PCR analysis with SYBR Green (Bio-Rad) using intron spanning primers: HSD11B1; FWD 5'-TAGGTTCTCTCTGTGTGTCCCA-3', REV 5'-TCCTCGAA GCATCTCTGGTCT-3'; IGFBP1 FWD 5'-CAGCAAACAGT GTGAGACTTCG-3', REV 5'-TCCCACTCCAAGGGTAGA CA-3'; GAPDH FWD 5'-CGTTCTCTGCCTTGACTGTG-3', REV 5'-TGACCCCTTCATTGACCTTC-3'. Data were analyzed using the $\Delta \Delta \mathrm{Ct}$ method in which Ct values of target genes are adjusted to corresponding Ct value of reference gene (GAPDH) (Livak \& Schmittgen 2001, Coleson et al. 2015). The experiment was repeated 3 independent times, and values are expressed as the mean \pm S.E.M. Means were separated using Student's $t$-test, and $* * *$ indicates significantly different means $(P<0.0001)$.

\section{Statistical analysis}

All experiments were independently repeated at least three times, and resulting values are expressed as the mean \pm S.E.M. Statistical analysis was done with GraphPad Prism 6.0. Means were separated using Newman-Keuls ANOVA or Student's $t$-Test and $*$ indicates significantly different means $(* P<0.05$ and $\left.{ }^{* * *} P<0.0001\right)$.

\section{Results}

PADs 2 and 4 are expressed in luminal and glandular epithelial cells in gestation day 25 ewe uterine cross sections

As PADs are expressed in mouse uterine luminal and glandular epithelial cells, we first examined if PADs are also expressed in ewe uterine cells on d25 of gestation. Paraffin-embedded uterine tissue was cut into $5 \mu \mathrm{M}$ sections and examined by IHC. Tissue sections were probed with an equal mass of non-specific IgG as control or primary antibodies against PADs 1-4. Imaging revealed that PAD2 and PAD4 expression localizes to luminal and glandular epithelial cells with sparse staining in adjacent stromal tissue (Fig. 1, panels B, I and D, J). In contrast, PAD1 and PAD3 display low levels of expression in luminal and glandular epithelial cells (Fig. 1, panels A and C). This is the first work to show
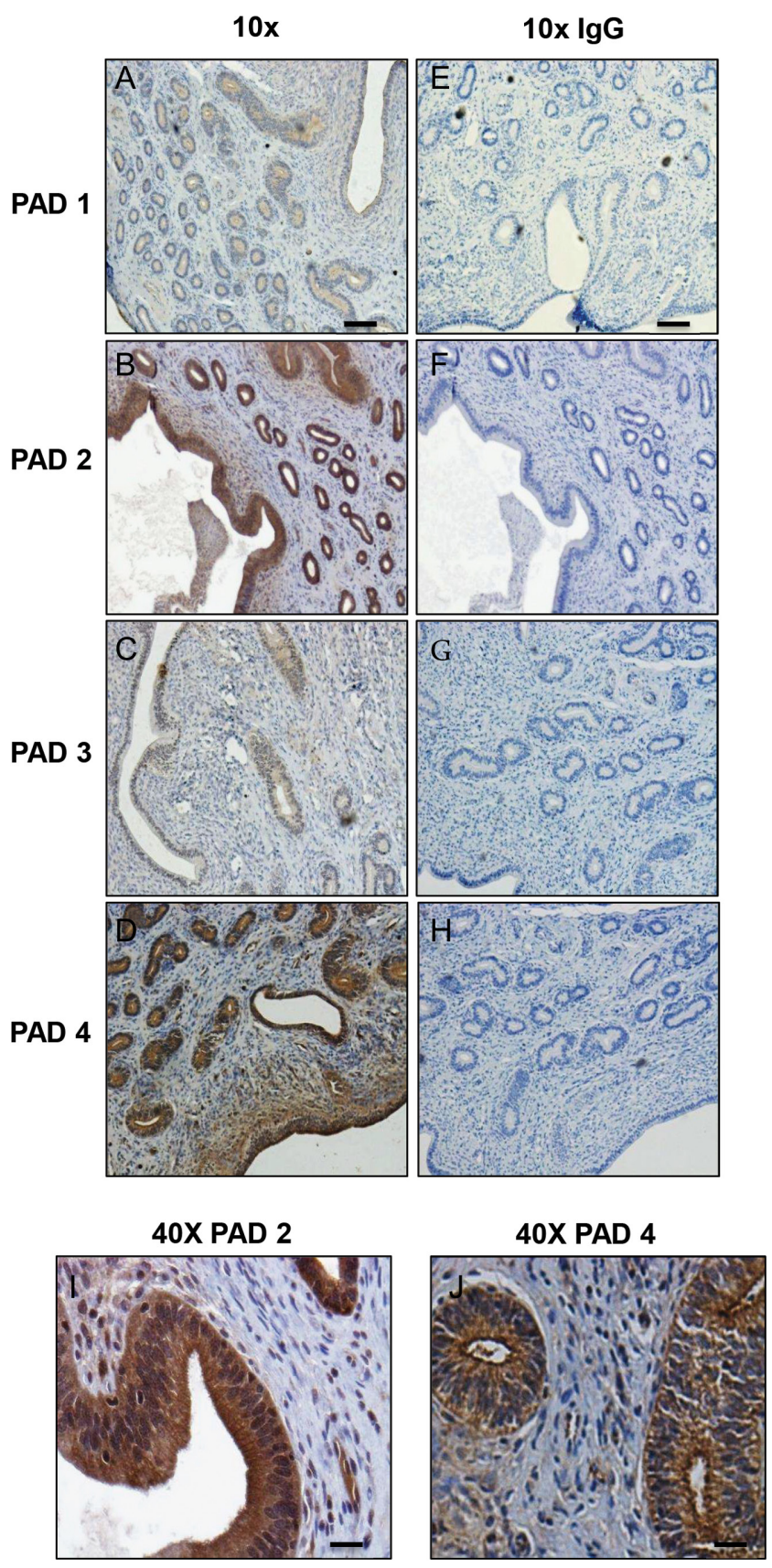

Figure 1 PADs 2 and 4 are expressed in luminal and glandular epithelial cells in gestation day 25 ewe uterine cross sections. Uterine tissue from pregnant ewes on d25 of gestation was harvested, fixed in $4 \%$ paraformaldehyde, embedded in paraffin and sectioned. $5 \mu \mathrm{m}$ uterine tissue sections were subject to a standard IHC protocol using rabbit anti-PAD1, PAD2, PAD3 and PAD4 antibodies or an equal amount of non-specific rabbit IgG as a control. Images were taken with a Zeiss Axio Vert. A1 microscope using the 10 and $40 \times$ objectives, and DAB staining represents PAD expression. Scale bars for $10 \times$ images are $100 \mu \mathrm{m}$, whereas scale bars in $40 \times$ images are $20 \mu \mathrm{m}$. 
that PADs are expressed in pregnant ewe uterine luminal and glandular epithelial cells and display a cellular localization pattern similar to that found in mouse uteri.

\section{PADs are catalytically active in gestation day 25 ewe caruncle lysates and citrullinate multiple proteins including histone $\mathrm{H} 3$ arginine residues}

Given that PADs are expressed in ewe uterine luminal and glandular epithelia, we hypothesized that the enzymes would be catalytically active and citrullinate proteins. To test this, we first examined PAD activity in caruncle lysates $(n=3)$ from ewes on $\mathrm{d} 25$ of gestation using the COLDER assay as described previously
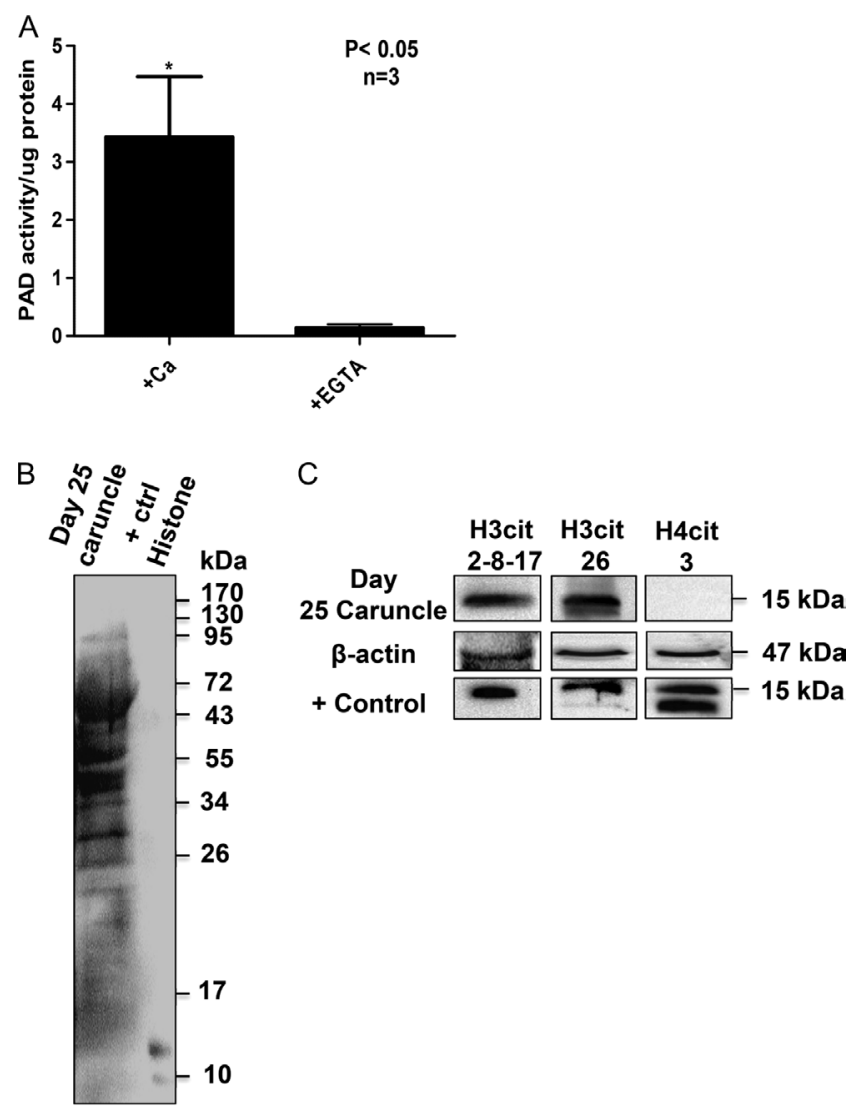

Figure 2 PADs are catalytically active in gestation day 25 ewe caruncle lysates and citrullinate multiple proteins including histone $\mathrm{H} 3$ arginine residues. (A) $20 \mu \mathrm{g}$ of caruncle lysate $(n=3)$ was incubated with $10 \mathrm{mM}$ calcium chloride or $50 \mathrm{mM}$ EGTA then subject to the COLDER assay. Values represent the mean \pm S.E.M. Means were separated using Student's $t$-test with * designating significant differences with treatment $(P<0.05)$. (B) Caruncle lysate was examined by western blot following the $\mathrm{AMC}$ protocol. The positive control is in vitro citrullinated bulk histones. (C) Caruncle lysates were examined by western blot, and membranes were probed with rabbit anti-histone $\mathrm{H} 3$ cit 2, 8 and 17, anti-histone $\mathrm{H} 3$ cit 26 and anti-histone $\mathrm{H} 4$ cit 3 antibodies and an anti- $\beta$-actin antibody as a loading control. The positive control is in vitro citrullinated bulk histones.
(Li et al. 2016). As PAD activity is highly calcium dependent, $20 \mu \mathrm{g}$ of caruncle lysate was incubated in the presence of $10 \mathrm{mM}$ calcium chloride or $50 \mathrm{mM}$ EGTA. Our results show that PADs are catalytically active, and that chelation of calcium significantly decreases activity $(P<0.05)$ (Fig. $2 \mathrm{~A})$. We next tested if citrullinated proteins are present in caruncle lysates. To do this, caruncle lysate was subjected to an anti-modified citrulline (AMC) western blot, which included in vitro citrullinated histones as a positive control (Li et al. 2016). Multiple citrullinated protein bands were detected (Fig. 2B); however, we achieved poor resolution of smaller-sized bands. Therefore, we next used western blots to examine if characterized antibodies could detect citrullinated arginine residues on histone tails in caruncle lysates. Membranes were probed with anti-H3cit 2, 8, 17, H3cit 26 and H4cit 3 antibodies and $\beta$-actin as a loading control. Western blots included in vitro citrullinated bulk histones as a positive control. Our results show that histone $\mathrm{H} 3$ arginine residues 2, 8, 17 and 26 are citrullinated; however, histone $\mathrm{H} 4$ arginine 3 is not (Fig. 2C). Taken together, our results suggest that PAD-catalyzed citrullination occurs in uterine luminal and glandular epithelial cells of ewes during pregnancy, and one target is arginine residues on histone $\mathrm{H} 3$ tails.
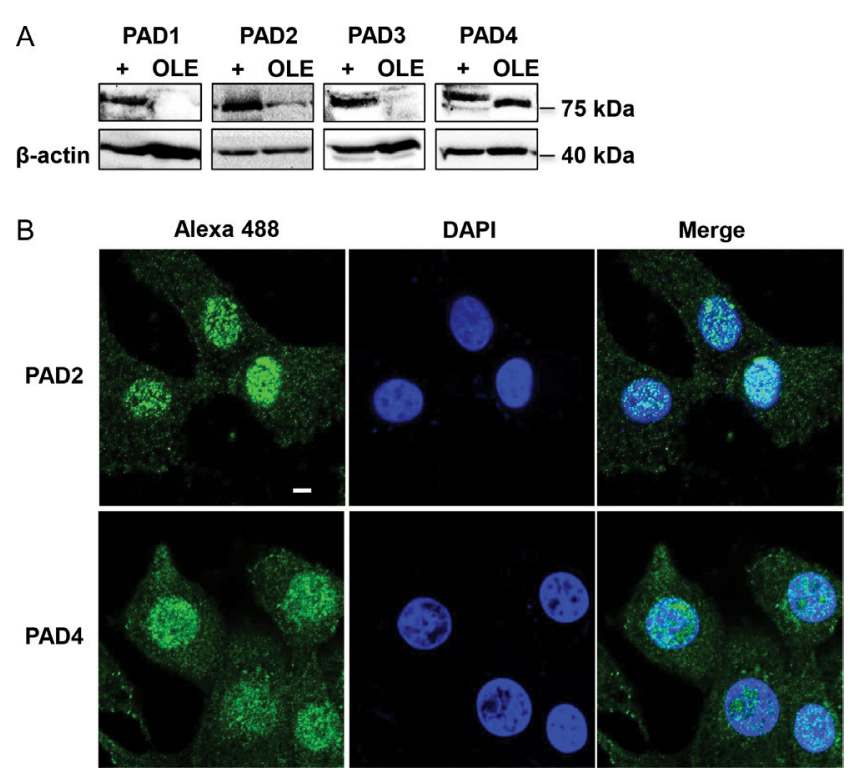

Figure 3 PADs 2 and 4 are expressed in the nuclei of the OLE cell line. (A) Equal amounts of OLE lysates were examined by western blot. Membranes were probed with rabbit anti-PAD1, PAD2, PAD3, PAD4 antibodies or anti- $\beta$-tubulin for a loading control. Positive controls $(+)$ were generated by the overexpression of PAD1-4 plasmids. (B) OLE cells were grown on glass bottom dishes then fixed, permeabilized and subjected to an IF protocol using anti-PAD2 and anti-PAD4 antibodies (green) and stained with DAPI (blue). Cells were imaged using a Zeiss LSM 710 confocal microscope using a $40 \times$ objective and scale bar is $5 \mu \mathrm{m}$. 
PADs 2 and 4 are expressed in the nuclei of the OLE cell line

We next wanted to test if genes are regulated by PAD-catalyzed histone citrullination in ewe uterine epithelial cells. To do so, we first needed to validate that OLE cells, which were initially isolated and characterized by Johnson et al., accurately recapitulate PAD expression patterns compared with gestation d25 ewe uterine tissue (Johnson et al. 1999). OLE cell lysates were examined by western blot in parallel with lysates in which human PAD 1-4 plasmids were overexpressed to generate positive controls (+) for PAD antibodies. Membranes were probed with anti-PAD $1-4$ antibodies or $\beta$-actin as a loading control. Our result highlights that PADs 2 and 4 are the predominant isozymes expressed in OLE cells (Fig. 3A).

We next used IF confocal microscopy to examine the subcellular localization of PADs 2 and 4 in OLE cells. OLE cells were fixed, probed with anti-PAD2 and PAD4 antibodies and then stained with DAPI. Our imaging results revealed that OLE cells have strong PAD2 and PAD4 staining within the nucleus (Fig. 3B). Thus, the OLE cells recapitulate PAD expression patterns detected in gestation $\mathrm{d} 25$ ewe uterine tissue and may serve as a suitable model to examine PADregulated gene expression.

\section{Histone $\mathrm{H} 3$ arginine residues $2,8,17$ and 26 are citrullinated in OLE cells}

As PADs 2 and 4 are expressed in the nuclei of OLE cells, we next tested if OLE cells display a similar citrullinated histone profile as that identified in gestation d25 caruncle lysates. To test this, equal concentrations of purified OLE histones were examined by western blot, which included in vitro citrullinated bulk histones as a positive control. Membranes were probed with anti-H3cit 2, 8, 17, H3cit 26 and H4cit 3 antibodies or total $\mathrm{H} 3$ as a loading control. Similar to gestation $\mathrm{d} 25$ caruncle lysates, histone arginine

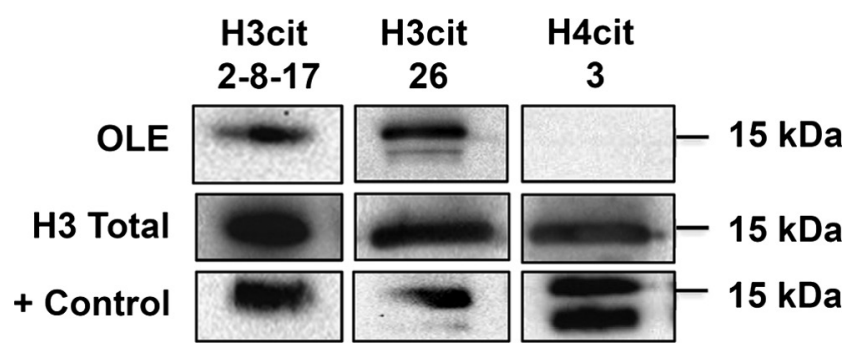

Figure 4 Histone $\mathrm{H} 3$ arginine residues 2, 8, 17 and 26 are citrullinated in OLE cells. OLE histones were purified by acid extraction, quantified and equal amounts were examined by western blot. Membranes were probed with rabbit anti-histone $\mathrm{H} 3$ cit 2, 8 and 17, anti-histone $\mathrm{H} 3$ cit 26, and anti-histone $\mathrm{H} 4$ cit 3 antibodies and an anti-histone $\mathrm{H} 3$ total antibody as a loading control. The positive control is in vitro citrullinated bulk histones. residues 2, 8, 17 and 26 are citrullinated; however, $\mathrm{H} 4$ arginine 3 is not (Fig. 4). These results indicate that citrullination of histone $\mathrm{H} 3$ arginine residues occurs in OLE cells.

\section{Treatment of OLE cells with the pan-PAD inhibitor $B B-C I A$ decreases histone citrullination}

We next tested if treatment with BB-ClA decreases histone citrullination in OLE cells. OLE cells were treated with vehicle (DMSO) or $2 \mu \mathrm{M}$ BB-ClA for 3 and $6 \mathrm{~h}$ at which point histones were isolated and quantified. Equal concentrations of histones were examined by western blot, and membranes were probed with anti-H3cit 2, 8 and 17 antibody and total $\mathrm{H} 3$ as a loading control. The representative western blot illustrates that $6 \mathrm{~h}$ of treatment with $2 \mu \mathrm{M}$ $\mathrm{BB}-\mathrm{ClA}$ reduces histone citrullination compared with vehicle-treated controls (Fig. 5A). Quantification of blots $(n=4)$ revealed that BB-ClA significantly

A
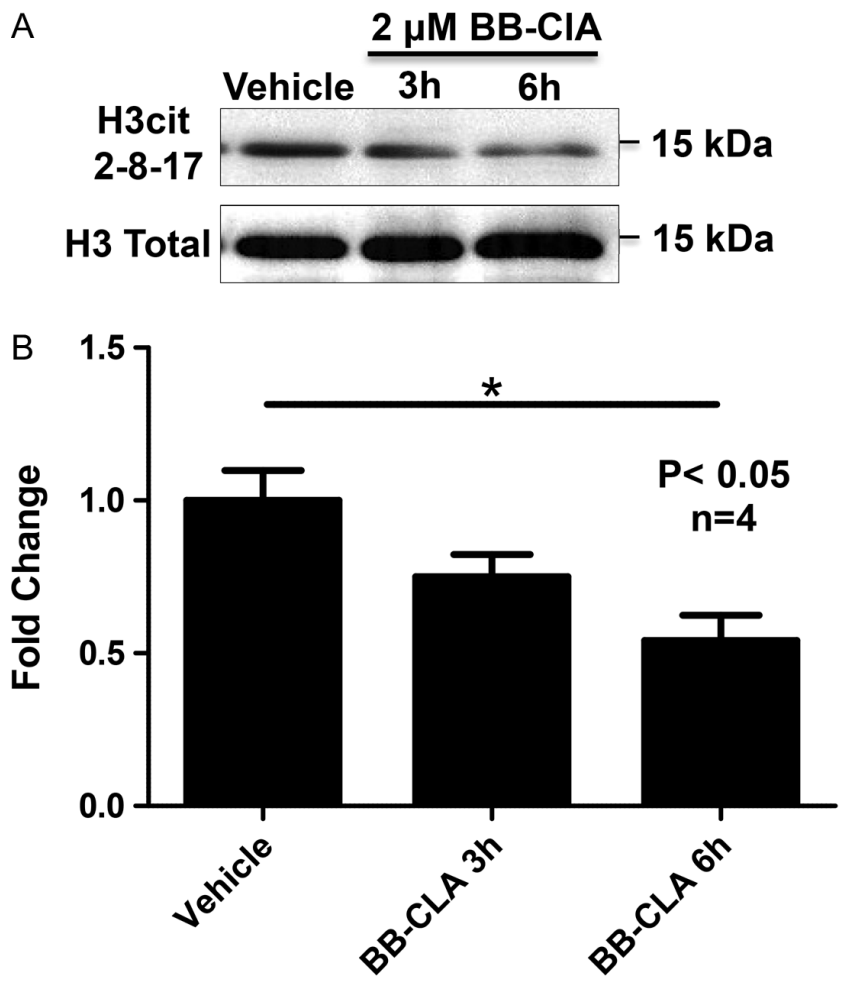

Figure 5 Treatment of OLE cells with the pan-PAD inhibitor BB-CIA decreases histone citrullination. (A) OLE cells were treated with vehicle (DMSO) or $2 \mu \mathrm{M}$ BB-ClA for 3 and $6 \mathrm{~h}$. After treatment, OLE histones were purified by acid extraction, quantified and equal amounts examined by western blot. Membranes were probed with a rabbit anti-histone $\mathrm{H} 3$ cit 2, 8 and 17 antibody, then stripped and reprobed with an anti-histone $\mathrm{H} 3$ total antibody as a loading control. (B) Quantitative analysis of the western blots $(n=4)$ was conducted using Bio-Rad ImageLab software and normalized to total histone $\mathrm{H} 3$ levels. Means were separated using Newman-Keuls ANOVA and * indicates significant differences $(P<0.05)$, whereas error bars represent the S.E.M. 
decreases histone $\mathrm{H} 3$ citrullination by approximately $50 \%$ following $6 \mathrm{~h}$ of treatment compared with vehicle-treated controls $(P<0.05)$ (Fig. 5B). Thus, BB-ClA significantly inhibits PAD-catalyzed citrullination of histones in OLE cells.
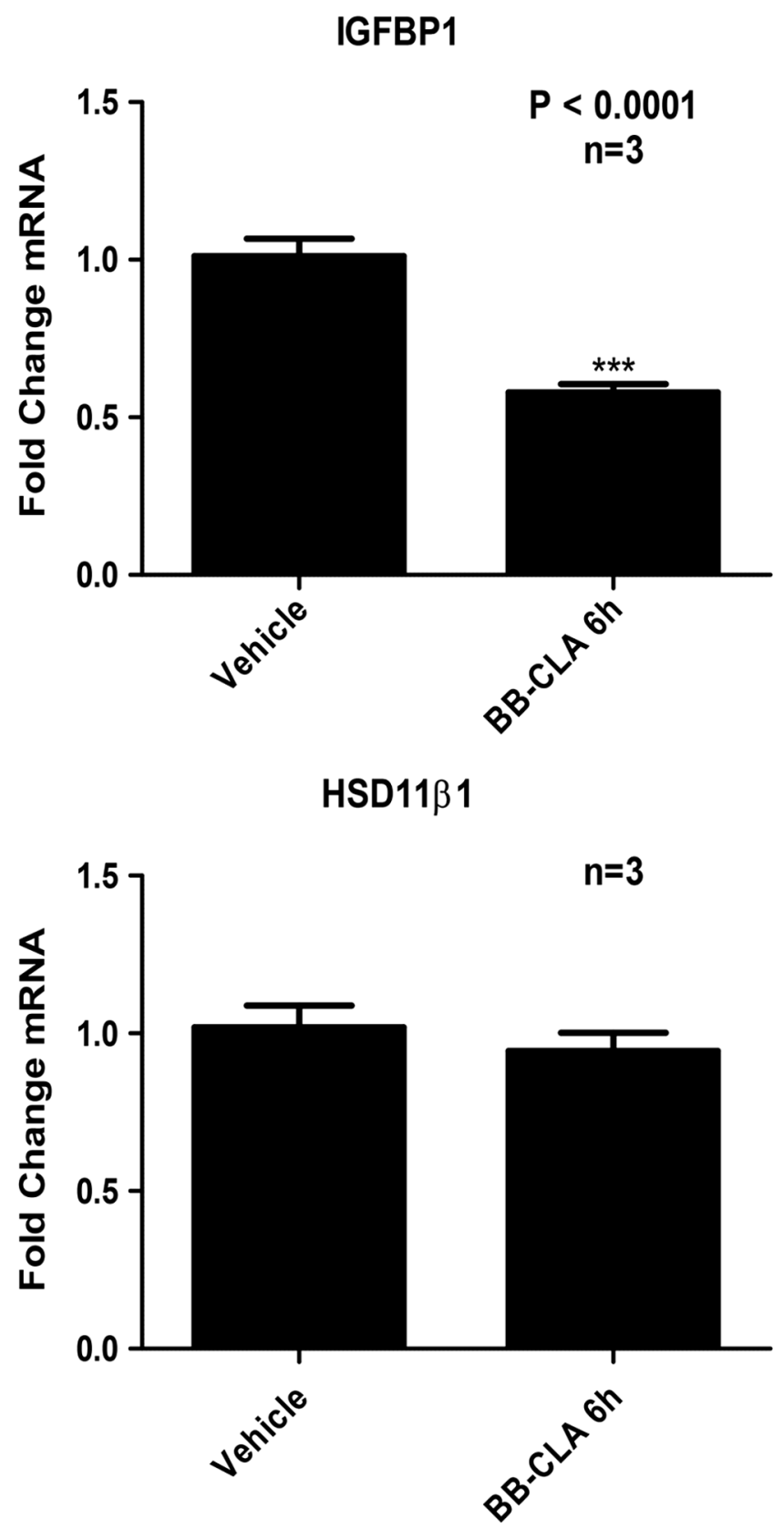

Figure 6 PAD inhibition decreases the expression of IGFBP1 mRNA in OLE cells. OLE cells were treated with vehicle (DMSO) or $2 \mu \mathrm{M}$ BB-CIA for 3 and $6 \mathrm{~h}$. Total RNA was purified from OLE cells, reverse transcribed and resulting CDNA was examined by qPCR with intron spanning primers for IGFBP1, HSD11B1 or GAPDH as the reference gene control. Data were analyzed using the $\triangle \triangle \mathrm{Ct}$ method where IGFBP1 and HSD11B1 Ct values were normalized to GAPDH and are represented as fold change in mRNA expression. Data are expressed as means \pm S.E.M. Means were separated using Student's $t$-test and ${ }^{* * *}$ indicates significant differences $(P<0.0001)$.

\section{PAD inhibition decreases the expression of IGFBP1 mRNA in OLE cells}

To determine if PAD-catalyzed citrullination regulates gene expression in OLE cells, we first identified two genes that are important during early pregnancy in the ewe. We examined the expression of IGFBP 1 and hydroxysteroid (11-B) dehydrogenase 1 (HSD11B1) based on their characterized expression patterns in uterine luminal epithelia (Gray et al. 2006, Spencer et al. 2008, Satterfield et al. 2009). OLE cells were treated with vehicle (DMSO) or $2 \mu \mathrm{M}$ BB-ClA for $6 \mathrm{~h}$, RNA was then purified from cells, reverse transcribed and resulting cDNA was examined by qPCR with primers specific for IGFBP1, HSD11B1 and GAPDH as the reference control gene. Our results show that inhibition of PAD-catalyzed citrullination in OLE cells results in a significant decrease in IGFBP1 mRNA expression $(P<0.0001)$, while having no effect on HSB11B1 (Fig. 6). This result suggests that PAD-catalyzed citrullination normally stimulates IGFBP1 expression in uterine luminal epithelial cells.

\section{Discussion}

The majority of pregnancy loss in humans and livestock occurs during early pregnancy (Macklon et al. 2002, Diskin et al. 2006, Dixon et al. 2007, Kwak-Kim et al. 2010). As such, significant effort has been expended to understand the relevant mechanisms to prevent such loss. One area under investigation is how the histotroph, produced by uterine luminal and glandular epithelial cells, regulates conceptus-uterine interactions. Underlying histotroph production is the activation of specific gene programs that encode the complex mixture of proteins, cytokines, growth factors and hormones required for implantation/attachment. Our work here has investigated the function of PAD-catalyzed citrullination in ewe uterine epithelial cells and identified a possible role in expression of a histotroph protein.

To address PAD function in uterine tissue, we first examined expression in uterine cross sections from pregnant ewes on $\mathrm{d} 25$ of gestation and found that PADs 2 and 4 are highly expressed, whereas the expression of PADs 1 and 3 is low. This finding is supported by our previous work showing strong PAD2 and PAD4 expression in mouse uterine luminal and glandular epithelial cells (Horibata et al. 2012). At present, it is unclear what stimulates PAD expression in uterine luminal and glandular epithelial cells. In estrogen receptor $\alpha$-knockout $(\alpha E R K O)$ and $\mathrm{KI} / \mathrm{KO}$ (ER-binding mutant) mice, uteri show decreased levels of PAD expression compared with those in wild-type mice indicating that $E R \alpha$ is important for expression (Hewitt et al. 2003). However, low ER $\alpha \mathrm{mRNA}$ and protein in the luminal and shallow glandular epithelia, combined with low serum estrogen on $\mathrm{d} 25$ of gestation in ewes indicates that this mechanism does not likely regulate 
PAD expression (Spencer \& Bazer 1995). In contrast, serum progesterone levels increase during the periimplantation period, but exogenous progesterone treatment of ovariectomized mice does not alter PAD expression over vehicle-treated controls (Takahara et al. 1992). Thus, autocrine and paracrine signals from maternal and embryonic tissues most likely regulate PAD expression during this period, and studies are currently underway to address this interesting question.

Multiple proteins are citrullinated in gestation d25 caruncle lysates. The identity and function of these citrullinated proteins is unknown, but it is an active area of research in our lab. Our studies did determine that histone $\mathrm{H} 3$ arginine residues 2, 8, 17 and 26 are citrullinated in OLE cells and gestation d25 caruncle lysates, but that histone $\mathrm{H} 4$ arginine 3 is not. Collectively, these results suggest that citrullination of specific arginine residues may govern the expression of gene programs in uterine luminal epithelial cells. Our previous studies in mammary epithelial cells also support that PAD2 and PAD4 localize to the nucleus and citrullinate-specific histone tail arginine residues to regulate gene expression (Cherrington et al. 2010, 2012, Zhang et al. 2011). Once in the nucleus, PADs hydrolyze the positive guanidinium group of arginine residues on histone $\mathrm{H} 2 \mathrm{~A}$, $\mathrm{H} 3$ and $\mathrm{H} 4$ tails to alter the charge association between DNA and histone octomers to decondense chromatin and subsequently alter gene expression (Hagiwara et al. 2002, Wang et al. 2004). Functionally, PADs antagonize histone arginine methylation by coactivator-associated arginine methyltransferase (CARM1) and protein arginine methyltransferase (PRMT1) (Wang et al. 2004). In addition to PADs, multiple isoforms of histone lysine demethylase are expressed in caruncle tissue from gestation day 90 ewes (Cleys et al. 2015). Interestingly, both epigenetic enzymes function as demethylases, which may be an important mechanism to regulate gene programs during pregnancy in ewe caruncle tissues.

The OLE cell line was isolated from ewe uterine luminal epithelial cells on day 5 of the estrous cycle (Johnson et al. 1999). It is important to note that endometrial cells from both pregnant and cyclic ewes, cattle and humans express similar genes important for receptivity and implantation (Kao et al. 2002, Brooks et al. 2014). In OLE cells, histone citrullination is attenuated by BB-CIA, which blocks PAD activity by covalently binding to the enzyme active site (Knight et al. 2015). BB-CLA significantly decreases PAD activity both in vitro and in vivo (Horibata et al. 2015, Knight et al. 2015). We next identified two potential target genes, IGFBP1 and HSD11B1, expressed in uterine luminal epithelial cells based on microarrays data sets; both genes have characterized roles during early pregnancy in ewes (Johnson et al. 2001, Spencer et al. 2004, 2008, Satterfield et al. 2009). In OLE cells, the inhibition of PAD-catalyzed citrullination did not alter the expression of HSD11B1; however, IGFBP1
mRNA levels were significantly decreased. Given this decrease, it is likely that PAD-catalyzed citrullination normally stimulates the expression of IGFBP1. IGFBP1 is secreted by uterine luminal and glandular epithelial cells to facilitate migration and attachment of the trophectoderm (Gleeson et al. 2001, Brooks et al. 2014). During the peri-implantation period, luminal epithelial cells secrete increasing amounts of IGFBP1, which temporally corresponds with the transformation of the blastocyst into a filamentous conceptus (Spencer et al. 2004, 2007). From a functional standpoint, IGFBP1 contains a tripeptide Arg-Gly-Asp (RGD) motif that binds the integrin heterodimer $\alpha 5 \beta 1$ to promote cell attachment. Mutation of the motif results in decreased migration of human trophoblast cells (Irwin \& Giudice 1998, Gleeson et al. 2001). In addition to the ewe, IGFBP1 is implicated as a regulator of implantation and placental development in other species (Giudice \& Saleh 1995, Robinson et al. 2000). Our work suggests that PAD-catalyzed citrullination facilitates the expression of IGFBP1, and therefore, may represent a novel mechanism contributing to trophoblast attachment in the ewe. It is also likely that PAD-catalyzed citrullination regulates the expression of additional genes involved in this process. Our follow-up studies are designed to identify the full cohort of genes regulated by PAD-catalyzed citrullination in uterine luminal epithelial cells.

Our work here further advances our knowledge of PAD function in uterine epithelial cells and begins to address a role for theses enzymes during early pregnancy. We propose that PAD-catalyzed citrullination may be an important mechanism used by uterine luminal epithelial cells to regulate histotroph gene expression during early pregnancy. If true, then modulating PAD-catalyzed citrullination could be a novel approach to regulate conceptus attachment to uterine tissue. Thus, this line of research may represent a new approach to investigate early pregnancy loss, which occurs in species ranging from humans to livestock.

\section{Declaration of interest}

The authors have no known conflict of interest and nothing to disclose except that P R T is a paid consultant to Bristol Myers Squibb.

\section{Funding}

This project was supported by grants from the National Center for Research Resources (P20RR016474) and the National Institute of General Medical Sciences (P20GM103432) from the National Institutes of Health (B D C) and by National Institute of General Medical Sciences grants GM079357 and GM110394 (P R T). The content is solely the responsibility of the author and does not necessarily represent the official views of the National Institutes of Health. This project was 
also supported by a grant from the New Mexico Agriculture Experiment Station (R A A).

\section{References}

Arai T, Kusubata M, Kohsaka T, Shiraiwa M, Sugawara K \& Takahara H 1995 Mouse uterus peptidylarginine deiminase is expressed in decidual cells during pregnancy. Journal of Cellular Biochemistry 58 269-278. (doi:10.1002/jcb.240580302)

Barrett T, Troup DB, Wilhite SE, Ledoux P, Rudnev D, Evangelista C, Kim IF, Soboleva A, Tomashevsky M, Marshall KA et al. 2009 NCBI GEO: archive for high-throughput functional genomic data. Nucleic Acids Research 37 D885-D890. (doi:10.1093/nar/gkn764)

Bazer FW 1975 Uterine protein secretions: relationship to development of the conceptus. Journal of Animal Science 41 1376-1382. (doi:10.2527/ jas1975.4151376x)

Brooks K, Burns G \& Spencer TE 2014 Conceptus elongation in ruminants: roles of progesterone, prostaglandin, interferon tau and cortisol. Journal of Animal Science Biotechnol 5 53. (doi:10.1186/2049-1891-5-53)

Carson DD, Bagchi I, Dey SK, Enders AC, Fazleabas AT, Lessey BA \& Yoshinaga K 2000 Embryo implantation. Developmental Biology 223 217-237. (doi:10.1006/dbio.2000.9767)

Cherrington BD, Morency E, Struble AM, Coonrod SA \& Wakshlag JJ 2010 Potential role for peptidylarginine deiminase 2 (PAD2) in citrullination of canine mammary epithelial cell histones. PLOS ONE 5 e11768. (doi:10.1371/journal.pone.0011768)

Cherrington BD, Zhang X, McElwee JL, Morency E, Anguish LJ \& Coonrod SA 2012 Potential role for PAD2 in gene regulation in breast cancer cells. PLOS ONE 7 e41242. (doi:10.1371/journal. pone.0041242)

Cleys ER, Halleran JL, Enriquez VA, da Silveira JC, West RC, Winger QA, Anthony RV, Bruemmer JE, Clay CM \& Bouma GJ 2015 Androgen receptor and histone lysine demethylases in ovine placenta. PLOS ONE 10 e0117472. (doi:10.1371/journal.pone.0117472)

Coleson MP, Sanchez NS, Ashley AK, Ross TT \& Ashley RL 2015 Human chorionic gonadotropin increases serum progesterone, number of corpora lutea and angiogenic factors in pregnant sheep. Reproduction 150 43-52. (doi:10.1530/REP-14-0632)

Diskin MG, Murphy J \& Sreenan JM 2006 Embryo survival in dairy cows managed under pastoral conditions. Animal Reproduction Science 96 297-311. (doi:10.1016/j.anireprosci.2006.08.008)

Dixon AB, Knights M, Winkler JL, Marsh DJ, Pate JL, Wilson ME, Dailey RA, Seidel G \& Inskeep EK 2007 Patterns of late embryonic and fetal mortality and association with several factors in sheep. Journal of Animal Science 85 1274-1284. (doi:10.2527/ jas.2006-129)

Giudice LC \& Saleh W 1995 Growth factors in reproduction. Trends in Endocrinology and Metabolism 6 60-69. (doi:10.1016/10432760(94)00205-I)

Gleeson LM, Chakraborty C, McKinnon T \& Lala PK 2001 Insulin-like growth factor-binding protein 1 stimulates human trophoblast migration by signaling through alpha 5 beta 1 integrin via mitogen-activated protein Kinase pathway. Journal of Clinical Endocrinology and Metabolism 86 2484-2493. (doi:10.1210/jc.86.6.2484)

Gray CA, Abbey CA, Beremand PD, Choi Y, Farmer JL, Adelson DL, Thomas TL, Bazer FW \& Spencer TE 2006 Identification of endometrial genes regulated by early pregnancy, progesterone, and interferon tau in the ovine uterus. Biology of Reproduction 74 383-394. (doi:10.1095/ biolreprod.105.046656)

Gray CA, Bazer FW \& Spencer TE 2001a Effects of neonatal progestin exposure on female reproductive tract structure and function in the adult ewe. Biology of Reproduction 64 797-804. (doi:10.1095/ biolreprod64.3.797)

Gray CA, Taylor KM, Ramsey WS, Hill JR, Bazer FW, Bartol FF \& Spencer TE $2001 \mathrm{~b}$ Endometrial glands are required for preimplantation conceptus elongation and survival. Biology of Reproduction 64 1608-1613. (doi:10.1095/biolreprod64.6.1608)

Gray CA, Burghardt RC, Johnson GA, Bazer FW \& Spencer TE 2002 Evidence that absence of endometrial gland secretions in uterine gland knockout ewes compromises conceptus survival and elongation. Reproduction 124 289-300. (doi:10.1530/rep.0.1240289)
Hagiwara T, Hidaka Y \& Yamada M 2005 Deimination of histone H2A and $\mathrm{H} 4$ at arginine 3 in HL-60 granulocytes. Biochemistry 44 5827-5834. (doi:10.1021/bi047505c)

Hagiwara T, Nakashima K, Hirano H, Senshu T \& Yamada M 2002 Deimination of arginine residues in nucleophosmin/B23 and histones in HL-60 granulocytes. Biochemical and Biophysical Research Communications 290 979-983. (doi:10.1006/bbrc.2001.6303)

Hewitt SC, Deroo BJ, Hansen K, Collins J, Grissom S, Afshari CA \& Korach KS 2003 Estrogen receptor-dependent genomic responses in the uterus mirror the biphasic physiological response to estrogen. Molecular Endocrinology 17 2070-2083. (doi:10.1210/me.2003-0146)

Horibata S, Coonrod SA \& Cherrington BD 2012 Role for peptidylarginine deiminase enzymes in disease and female reproduction. Journal of Reproduction and Development 58 274-282. (doi:10.1262/jrd.2011040)

Horibata S, Vo TV, Subramanian V, Thompson PR \& Coonrod SA 2015 Utilization of the soft agar colony formation assay to identify inhibitors of tumorigenicity in breast cancer cells. Journal of Visualized Experiments e52727. (doi:10.3791/52727)

Irwin JC \& Giudice LC 1998 Insulin-like growth factor binding protein-1 binds to placental cytotrophoblast alpha5beta1 integrin and inhibits cytotrophoblast invasion into decidualized endometrial stromal cultures. Growth Hormone and IGF Research 8 21-31. (doi:10.1016/S10966374(98)80318-3)

Jiang Z, Cui Y, Wang L, Zhao Y, Yan S \& Chang X 2013 Investigating citrullinated proteins in tumour cell lines. World Journal of Surgical Oncology 11 260. (doi:10.1186/1477-7819-11-260)

Johnson GA, Bazer FW, Jaeger LA, Ka H, Garlow JE, Pfarrer C, Spencer TE \& Burghardt RC 2001 Muc-1, integrin, and osteopontin expression during the implantation cascade in sheep. Biology of Reproduction 65 820-828. (doi:10.1095/biolreprod65.3.820)

Johnson GA, Burghardt RC, Newton GR, Bazer FW \& Spencer TE 1999 Development and characterization of immortalized ovine endometrial cell lines. Biology of Reproduction 61 1324-1330. (doi:10.1095/ biolreprod61.5.1324)

Kane MT, Morgan PM \& Coonan C 1997 Peptide growth factors and preimplantation development. Human Reproduction Update $\mathbf{3}$ 137-157. (doi:10.1093/humupd/3.2.137)

Kao LC, Tulac S, Lobo S, Imani B, Yang JP, Germeyer A, Osteen K, Taylor RN, Lessey BA \& Giudice LC 2002 Global gene profiling in human endometrium during the window of implantation. Endocrinology 143 2119-2138. (doi:10.1210/endo.143.6.8885)

Kholia S, Jorfi S, Thompson PR, Causey CP, Nicholas AP, Inal JM \& Lange S 2015 A novel role for peptidylarginine deiminases in microvesicle release reveals therapeutic potential of PAD inhibition in sensitizing prostate cancer cells to chemotherapy. Journal of Extracellular Vesicles $\mathbf{4}$ 26192. (doi:10.3402/jev.v4.26192)

Knight JS, Subramanian V, O'Dell AA, Yalavarthi S, Zhao W, Smith CK, Hodgin JB, Thompson PR \& Kaplan MJ 2015 Peptidylarginine deiminase inhibition disrupts NET formation and protects against kidney, skin and vascular disease in lupus-prone MRL/lpr mice. Annals of the Rheumatic Diseases 74 2199-2206. (doi:10.1136/annrheumdis-2014-205365)

Knuckley B, Causey CP, Jones JE, Bhatia M, Dreyton CJ, Osborne TC, Takahara H \& Thompson PR 2010 Substrate specificity and kinetic studies of PADs 1, 3, and 4 identify potent and selective inhibitors of protein arginine deiminase 3. Biochemistry 49 4852-4863. (doi:10.1021/ bi100363t)

Kwak-Kim J, Park JC, Ahn HK, Kim JW \& Gilman-Sachs A 2010 Immunological modes of pregnancy loss. American Journal of Reproductive Immunology 63 611-623. (doi:10.1111/j.16000897.2010.00847.x)

Li G, Hayward IN, Jenkins BR, Rothfuss HM, Young CH, Nevalainen MT, Muth A, Thompson PR, Navratil AM \& Cherrington BD 2016 Peptidylarginine deiminase 3 (PAD3) is upregulated by prolactin stimulation of CID-9 cells and expressed in the lactating mouse mammary gland. PLOS ONE 11 e0147503. (doi:10.1371/journal. pone.0147503)

Livak KJ \& Schmittgen TD 2001 Analysis of relative gene expression data using real-time quantitative PCR and the 2(-Delta Delta C(T)) Method. Methods 25 402-408. (doi:10.1006/meth.2001.1262)

Macklon NS, Geraedts JP \& Fauser BC 2002 Conception to ongoing pregnancy: the 'black box' of early pregnancy loss. Human Reproduction Update 8 333-343. (doi:10.1093/humupd/8.4.333) 
Quinn KE, Ashley AK, Reynolds LP, Grazul-Bilska AT \& Ashley RL 2014 Activation of the CXCL12/CXCR4 signaling axis may drive vascularization of the ovine placenta. Domestic Animal Endocrinology 47 11-21. (doi:10.1016/j.domaniend.2013.12.004)

Roberts RM, Murray MK, Burke MG, Ketcham CM \& Bazer FW 1987 Hormonal control and function of secretory proteins. Advances in Experimental Medicine and Biology 230 137-150. (doi:10.1007/978-14684-1297-0_8)

Robinson RS, Mann GE, Gadd TS, Lamming GE \& Wathes DC 2000 The expression of the IGF system in the bovine uterus throughout the oestrous cycle and early pregnancy. Journal of Endocrinology 165 231-243. (doi:10.1677/joe.0.1650231)

Rus'd AA, Ikejiri Y, Ono H, Yonekawa T, Shiraiwa M, Kawada A \& Takahara H 1999 Molecular cloning of cDNAs of mouse peptidylarginine deiminase type I, type III and type IV, and the expression pattern of type I in mouse. European Journal of Biochemistry 259 660-669. (doi:10.1046/j.14321327.1999.00083.x)

Satterfield MC, Song G, Kochan KJ, Riggs PK, Simmons RM, Elsik CG, Adelson DL, Bazer FW, Zhou H \& Spencer TE 2009 Discovery of candidate genes and pathways in the endometrium regulating ovine blastocyst growth and conceptus elongation. Physiological Genomics 39 85-99. (doi:10.1152/physiolgenomics.00001.2009)

Shechter D, Dormann HL, Allis CD \& Hake SB 2007 Extraction, purification and analysis of histones. Nature Protocols 2 1445-1457. (doi:10.1038/ nprot.2007.202)

Spencer TE \& Bazer FW 1995 Temporal and spatial alterations in uterine estrogen receptor and progesterone receptor gene expression during the estrous cycle and early pregnancy in the ewe. Biology of Reproduction 53 1527-1543. (doi:10.1095/biolreprod53.6.1527)

Spencer TE, Johnson GA, Bazer FW \& Burghardt RC 2004 Implantation mechanisms: insights from the sheep. Reproduction 128 657-668. (doi:10.1530/rep.1.00398)

Spencer TE, Johnson GA, Bazer FW \& Burghardt RC 2007 Fetal-maternal interactions during the establishment of pregnancy in ruminants. Society of Reproduction and Fertility Supplement 64 379-396. (doi:10.5661/ rdr-vi-379)

Spencer TE, Sandra O \& Wolf E 2008 Genes involved in conceptusendometrial interactions in ruminants: insights from reductionism and thoughts on holistic approaches. Reproduction 135 165-179. (doi:10.1530/REP-07-0327)

Takahara H, Kusubata M, Tsuchida M, Kohsaka T, Tagami S \& Sugawara K 1992 Expression of peptidylarginine deiminase in the uterine epithelial cells of mouse is dependent on estrogen. Journal of Biological Chemistry $267520-525$.

Takahara H, Tsuchida M, Kusubata M, Akutsu K, Tagami S \& Sugawara K 1989 Peptidylarginine deiminase of the mouse. Distribution, properties, and immunocytochemical localization. Journal of Biological Chemistry 264 13361-13368.

Terakawa H, Takahara H \& Sugawara K 1991 Three types of mouse peptidylarginine deiminase: characterization and tissue distribution. Journal of Biochemistry 110 661-666.

Vossenaar ER, Zendman AJ, van Venrooij WJ \& Pruijn GJ 2003 PAD, a growing family of citrullinating enzymes: genes, features and involvement in disease. Bioessays 25 1106-1118. (doi:10.1002/bies.10357)

Wang Y, Wysocka J, Sayegh J, Lee YH, Perlin JR, Leonelli L, Sonbuchner LS, McDonald CH, Cook RG, Dou Y et al. 2004 Human PAD4 regulates histone arginine methylation levels via demethylimination. Science 306 279-283. (doi:10.1126/science.1101400)

Wright PW, Bolling LC, Calvert ME, Sarmento OF, Berkeley EV, Shea MC, Hao Z, Jayes FC, Bush LA, Shetty J et al. 2003 ePAD, an oocyte and early embryo-abundant peptidylarginine deiminase-like protein that localizes to egg cytoplasmic sheets. Developmental Biology 256 73-88. (doi:10.1016/S0012-1606(02)00126-4)

Zhang X, Gamble MJ, Stadler S, Cherrington BD, Causey CP, Thompson PR, Roberson MS, Kraus WL \& Coonrod SA 2011 Genome-wide analysis reveals PADI4 cooperates with Elk-1 to activate c-Fos expression in breast cancer cells. PLoS Genetics 7 e1002112. (doi:10.1371/journal. pgen.1002112)

Received 7 September 2016

First decision 26 September 2016

Revised manuscript received 28 September 2016

Accepted 10 October 2016 